\title{
Oilseed production and sustainable development in northern Brazil: impact on farm income and food security
}

\author{
Marcus Vinícius Alves Finco ${ }^{1}$, Fernanda Dias Bartolomeu Abadio Finco ${ }^{2}$
}

\begin{abstract}
Biofuel production has been a greatly discussed topic in Brazil. In 2004, these debates lead the country to develop new policies and to implement a national program for biodiesel use and production (PNPB) with the intent to increase the share of renewable energy and foster regional development. In this context, the present study aimed to assess the impact of small-scale oilseed production on income generation, as well as on food production. For this purpose, a cross sectional study was conducted with family farmers in the state of Tocantins, in a transition area between the Savannah and the Amazon rain forest. Ranges of socio-economic indicators were collected among smallholders who cultivate Jatropha curcas and Ricinus communis. The preliminary results point towards a negative relationship between oilseed activity and local food production, harming the local food security. In addition, the farm income generated by the oilseed activity is lower than conventional crops, such as maize and cassava, for instance. This research is unprecedented in the region and the results can be extremely valuable in supporting regional and national policies on clean energy; helping Brazil to achieve the regional sustainable development.
\end{abstract}

Key-words: biofuels, farm income, food security, Brazil.

\section{Produção de sementes oleaginosas e desenvolvimento sustentável no norte do Brasil: impactos sobre a renda agrícola e segurança alimentar}

A produção de biocombustíveis tem sido amplamente debatida no Brasil, o que levou o país a desenvolver e a implantar, no ano de 2004, o Programa Nacional de Produção e Uso de Biodiesel (PNPB), com a intenção de aumentar a participação de energias renováveis na matriz energética brasileira e, ao mesmo tempo, promover o desenvolvimento regional. Neste contexto, o presente estudo busca avaliar os impactos da produção em pequena escala de sementes oleaginosas na geração de renda, bem como os impactos na produção local de alimentos. Para isso, um estudo transversal foi realizado com agricultores familiares no Estado do Tocantins, em uma região de transição entre o Cerrado e a Floresta Amazônica. Indicadores sócio-econômicos foram coletados entre os agricultores que cultivam pinhão manso (Jatropha curcas) e mamona (Ricinus communis). Os resultados preliminares apontam para uma relação negativa entre a produção de sementes oleaginosas e a produção local de alimentos, agravando a situação de insegurança alimentar dos agricultores. Além disso, a renda agrícola proveniente da produção de sementes oleaginosas é menor se comparada a outras culturas tradicionais como o milho e a mandioca, por exemplo. A pesquisa é inédita na região e os resultados podem ser extremamente eficazes no apoio e subsídio às políticas regionais e nacionais na busca pelo desenvolvimento regional sustentável.

Palavras-chave: biocombustíveis, renda agrícola, segurança alimentar, Brasil.

\footnotetext{
${ }^{1}$ Docente, Universidade Federal do Tocantins (UFT), Laboratório de Segurança Alimentar e Nutricional (LabSAN). Av. NS 15, ALC NO 14, 109 Norte, CEP 77001-090, Palmas, TO. Dr. pelo Institute of Agricultural Economics in the Tropics and Subtropics. University of Hohenheim, Stuttgart, Germany. E-mail:marcus.finco@gmail.com.

${ }^{2}$ Docente, Universidade Federal do Tocantins, Laboratório de Segurança Alimentar e Nutricional (LabSAN). Av: NS 15, ALC NO 14, 109 Norte, CEP 77001-090, Palmas/TO, Brasil
} 


\section{INTRODUCTION}

The global concern for the depredation and exhaustion of natural resources has led governments and scientists around the world to identify alternatives and solutions to the problem. Since the beginning of $21^{\text {st }}$ century, an international debate has taken shape, which is currently discussed at 10 out of 10 meetings on sustainable development around the world: biofuels and its pros and cons $[1,2,3]$. From a socio-economic point of view, biofuels can positively impact rural development and diversify the utilization of the local environment. For example, enhancing rural space multi-functionality, where farms are used not only for crop production, but also eco tourism and, of course, generating strategies that reduce and alleviate poverty, so-called 'pro-poor' strategies [4,5,6].

Despite of the numerous advantages, some questions have been raised regarding the possible negative externalities generated by biofuel production. These include the decrease in local food production and supply, as well as, negative impacts on environmental services and climate change [2]. Regarding the food supply issue, for instance, the main concern is that biofuels may compete with food crops. This competition for land becomes an issue especially when some of the crops (e.g. maize and soybean), which are currently cultivated for food and feed, are redirected towards the production of biofuels. As foodoriented agricultural land is converted to biofuel production, significant negative impacts on food security can be observed, the so-called "food versus fuel" debate $[7,8,9]$.

Moreover, one of the main disadvantages of biofuels is that they can be a threat to regional biodiversity and the climate. This is especially observed through the deforestation of native biomes, such as, savannah and rain forests, and the impact of introducing invasive species for biofuel production. Land use changes associated with expanded biofuel production can have major impacts. By converting forestland to biofuel crops or agricultural crops to biofuel feed stocks, large quantities of carbon are released that would take years to recover through the emission reductions achieved by substituting biofuels for fossil fuels [2].

Therefore, in 2004, Brazil launched a biodiesel program, the National Program of Biodiesel Use and Production (PNPB), which is based on a scenario of high oil prices, a growing demand for fuels from renewable sources, and the country's comparative advantage in natural resources [10]. Moreover, the PNPB has several specific objectives, such as, reducing the import of diesel. Brazil would increase its independence, increase the share of renewable energy on the National energy matrix, foster rural development and increase the share of small-scale farmers in the biodiesel chain through social inclusion by implementing PNPB [11].

Regarding Food and Nutrition Security (FNS), Brazil has significantly advanced on this topic. During the II CNSAN (National Conference of Food and Nutrition Security) in 2004 [12], under a participatory process, a Brazilian definition of "Food and Nutrition Security" was established and a specific policy for the country was designed, both of which consider sustainable development, as follows:

Food and Nutrition Security is the achievement of the right to all people to access food regularly and permanently, with enough quality and quantity, without compromise the access to other basic needs, based on food practices to promote health, with respect to cultural differences and being social, economic and environmentally sustainable (II CNSAN, 2004, p. 4).

Based on this definition, it is clear that FNS is connected to sustainable development, as well as, all other issues related to its achievement. Social inclusion and income generation, which can promote access to food, is also included in the FNS debate and policies. Not least, the preservation of biodiversity is essential to assure sustainability and, therefore, is also included in food and nutrition security in Brazil. It is not possible or advisable to remove one of the above-mentioned topics based on the Brazilian guidelines for FNS. Furthermore, it is important to mention that the III CNSAN (2007) [13] concluded that an increase in biofuels cannot interfere with internal food production and must promote the generation of income for farmers. Also, actions on FNS should follow an interdepartmental and interdisciplinary approach, as the PNPB can also be considered an interdepartmental initiative. 
However, now 6 years since its implementation, the impacts of the Brazilian biodiesel program remain uncertain, especially regarding local food and nutrition security and regional sustainable development. Thus, the present study aims to analyze the relationship and links between the small-scale oil seed production and the impacts on farm income generation, as well as on local food production. The present study should support the regional and national governments in improving the PNPB and food and nutrition security targets. Moreover, the results presented can play an important role in integrating efforts to consolidate a new economic alternative for the small-scale farmers without harming local food production.

\section{RESEARCH \\ AREA METHODOLOGICAL ASPECTS}

AND

The research was carried out in Tocantins State, located in northern Brazil in a region well known as Brazilian Legal Amazon. The State is situated in a transition area, presenting climate and vegetation from Amazon rain forest (15\% of the territory) and Cerrado (85\% of the territory) [14]. This transition area, so-called Ecotone zone, is the home to traditional communities (family agriculture, indigenous, as well as, quilombolas ${ }^{3}$ ) and comprises rich biodiversity, which is responsible for numerous environmental services. For this reason, scientific studies and research in the area are extremely important. Often they are focused on understanding the different farming systems and their connections to the local economy and the very diverse environment.

Data collection necessary to create the database was formed through a comprehensive survey, which was carried out between April and September 2008 in two sub-study regions within Tocantins State. In one sub-study region, Ricinus communis (castor bean and also well known as mamona in Brazil) oil seed cultivated and in the other sub study-region Jatropha curcas (well known as pinhão manso in Brazil) is cultivated.

Specific questionnaires ${ }^{4}$ were applied to smallholders, who were randomly selected: 27 in the case of Jatropha curcas producers (JC); and 25 in the case of Ricinus communis producers (RC). It is important to highlight that the selection of smallholders followed statistical procedures and that the sample can be considered representative since it comprises more than $90 \%$ of small-scale oil seed producers in the region in question.

On completion of the field survey, the data was transferred from the questionnaires into a Microsoft Excel worksheet as a data base file. The data was then separated into several sub-topics, such as household identification, farm, off-farm activities, resources, oil seed production, and so on. With the data bank in place, Box and Whisker Plots were used as a detection method for outliers in quantitative data. Extreme values, wrong answers and mistakes in data entry were addressed, and all missing values were replaced by the arithmetic means.

The economic analysis involves statistical methods utilizing exploratory and descriptive data analysis. Continuous variables were presented with mean values and their respective standard error. The distribution similarities were checked through the Kolmogorov-Smirnov test. Association among categorical variables was checked by Chi-square test $\left(\chi^{2}\right)$, whereas $t$-student and Mann-Whitney $U$ tests were used for symmetric and asymmetric distributions, respectively. The Kruskal-Wallis test was applied using the Dunn procedure in sequence, aiming at verifying differences among non parametric distribution means. The statistical tests were done using the software STATA.

\section{RESULTS AND DISCUSSION}

\section{Food production and impacts on food security}

The food security of local communities is affected by the relationship between oil seed activity and food production. Therefore, it is necessary to present, ex ante, an overall picture of the total food consumption by families, as well as, the quantity of food produced by them. This picture (Figure 1) is important since it approximates of the quantity of food produced within the rural property and the quantity that must be purchased at the market. In this context, Table 1 focuses on the most produced and consumed feedstock of local families.

\footnotetext{
${ }^{3}$ Descendants of African slaves.

4 The specific questionnaires comprise economic, financial, social, environmental, cultural and other aspects of the farmers' living standard.
} 
As one can notice in Table 1, consumption of both groups follows the typical Brazilian food pattern where rice and beans are considered staple foods. All families had shown the same consumption profile of rice and beans, as the consumption of these two foods had no significant statistical difference between groups $(p<0.05)$. Cassava which could also be considered as a staple food in the northern Brazil presented the same amount of consumption $(p<0.05)$. However, families of JC group obtain most of their cassava consumption from the property when compared to RC group. Indeed, it is important to highlight that families in both groups (Ricinus communis and Jatropha curcas) have to buy a considerable part of their consumed food at local markets: $86 \%$ of rice, $90 \%$ of bean and $73 \%$ of cassava has to be purchased by smallholders in the RC group; and $65 \%$ of rice, $88 \%$ of bean and $29 \%$ of cassava has to be purchased by smallholders in the JC group. This demonstrates that families depend on local market to fulfill their needs, i.e. relying only on self-production is not sufficient to feed the family and, therefore, families in the region in question can be considered as food net buyers.

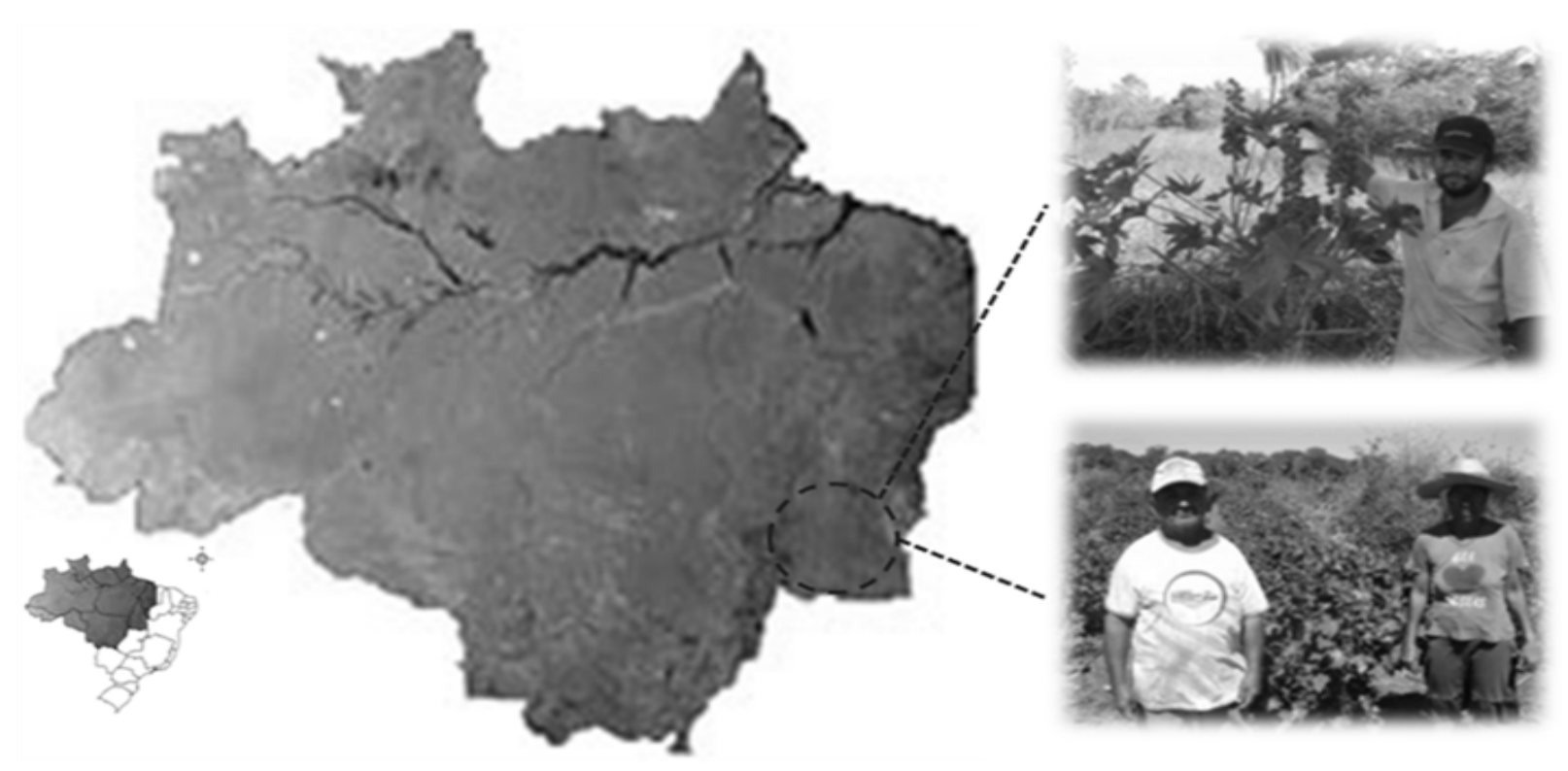

Figure 1. Research area within the Brazilian Legal Amazon Region.

Table 1. Amount of food consumed by families, per year.

\begin{tabular}{lrrrrr}
\hline \multirow{2}{*}{$\begin{array}{l}\text { Quantity of food consumption } \mathbf{( k g )} \\
\end{array}$} & \multicolumn{2}{c}{$\begin{array}{c}\text { Ricinus communis } \\
\text { producers }\end{array}$} & \multicolumn{2}{c}{$\begin{array}{c}\text { Jatropha curcas } \\
\text { producers }\end{array}$} \\
\cline { 2 - 6 } & \multicolumn{1}{c}{ Mean } & \multicolumn{1}{c}{ SE } & Mean & \multicolumn{1}{c}{ SE } & p-value \\
\hline Total amount of rice consumption & 276.80 & 26.43 & 204.44 & 9.09 & 0.06 \\
Rice from the property & 36.80 & 14.03 & 71.85 & 10.65 & 0.09 \\
Total amount of bean consumption & 87.36 & 9.28 & 78.22 & 6.84 & 0.34 \\
Bean from the property & 8.16 & 3.25 & 9.18 & 5.70 & 0.07 \\
Total amount of cassava consumption & 417.60 & 4.21 & 415.55 & 4.41 & 0.21 \\
Cassava from the property & 112.80 & 26.22 & 294.81 & 29.38 & $<0.00$ \\
\hline
\end{tabular}

Source: Research results (2008).

Notes: SE $=$ standard error of the mean.

Mann-Whitney test was applied to check the differences between means $(p<0.05)$. 
As shown in Table 2, there was no statistical difference between both groups regarding the total crop area and land changed area to oil seed activity $(p<$ $0.05)$. When asked about the area used to cultivate oil seeds, 11 families (44\%) in RC group and 15 families $(55.6 \%)$ in JC group responded they have changed the land use from ordinary feedstock cultivation, such as maize, rice, cassava to Ricinus and Jatropha production, respectively. Table 2 illustrates that at least $27 \%$ of the feedstock area in the RC group and $47 \%$ of the feedstock in JC group has been changed to the oil seed activity.

Table 2. Total crop area and land changed to oil seed activity.

\begin{tabular}{lccccc}
\hline \multirow{2}{*}{ Hectares } & \multicolumn{3}{c}{$\begin{array}{c}\text { Ricinus communis } \\
\text { producers }\end{array}$} & \multicolumn{2}{c}{$\begin{array}{c}\text { Jatropha curcas } \\
\text { producers }\end{array}$} \\
\cline { 2 - 6 } & Mean & SE & Mean & SE & p-value \\
\hline Total crop area & 2.66 & 0.63 & 2.87 & 0.51 & 0.44 \\
Area changed to oil seed activity & 0.74 & 0.20 & 1.37 & 0.26 & 0.08 \\
\hline
\end{tabular}

Source: Research results (2008).

Notes: $\mathrm{SE}=$ standard error of the mean.

Mann-Whitney test was applied to check the differences between the means $(p<0.05)$.

In addition to the figures presented in Table 1 and Table 2, when families were inquired about food shortage during the year, $56 \%$ of smallholders in RC group responded positively, i.e. they suffer, in some level, of food deficit during the year, against $25.9 \%$ of smallholders in JC group whom responded similarly. Besides the difference in the figures, one can be assured that at least one fourth of the families in JC group face deficits on food consumption and what is more serious, more than a half of the families in $\mathrm{RC}$ group have to cope with food shortage during the year. These results raise an important question in the context of food rights and highlight the ongoing discussion about the effect of biofuels on food insecurity. Table 3 shows the relationship between oil seed activity and feedstock land converted oil seed production from two different scenarios. The first scenario (scenario A) is established based on the current land used, on average, to produce the main feedstock, such as, rice, maize, bean and cassava.

This scenario reflects the current situation, i.e. the situation after the adoption of oil seed activity by families. Moreover, the current production of feedstock, on average, is also presented for each group: $\mathrm{RC}$ and JC, respectively. The second scenario (scenario
B) represents a situation where families did not adopt oil seed activity. Here the estimation was based on all land that was used previously to produce feedstock, i.e. available land before the adoption of oil seed activity. Again, the potential production of feedstock, on average per family, is presented and one can observe the differences, expressed by $\Delta \%$.

In 2007 the Brazilian Ministry of Agrarian Development (MDA) published a report on the implementation of the biodiesel program and stated that there is no risk of a competition between the production of biodiesel and food, for the following reasons: (i) oil need for biodiesel is grown through oil crops and results in unused fiber, that can serve as animal feed or natural fertilizer and ; (ii) the cultivation of primary materials tends to occupy soils of less economic interest or during periods between the main crops [15]. However, as illustrated in Table 3, there was a conversion of land to oil seed production from all four feedstock production areas analyzed, especially regarding rice and cassava in the case of $\mathrm{RC}$ group (48.2\% and $34.4 \%$, respectively), and cassava and maize in the case of JC group ( $40 \%$ and $31.3 \%$, respectively). 
Table 3. Area and production scenarios with and without the oil seed activity.

\begin{tabular}{|c|c|c|c|c|c|c|c|c|c|c|}
\hline \multirow{3}{*}{ Activity } & \multicolumn{5}{|c|}{$\begin{array}{c}\text { Ricinus communis } \\
\text { producers }\end{array}$} & \multicolumn{5}{|c|}{$\begin{array}{c}\text { Jatropha curcas } \\
\text { producers }\end{array}$} \\
\hline & \multicolumn{2}{|c|}{ Scenario A } & \multicolumn{2}{|c|}{ Scenario B } & \multirow[b]{2}{*}{$\Delta \%$} & \multicolumn{2}{|c|}{ Scenario A } & \multicolumn{2}{|c|}{ Scenario B } & \multirow[b]{2}{*}{$\Delta \%$} \\
\hline & Mean & SE & Mean & SE & & Mean & SE & Mean & SE & \\
\hline \multicolumn{11}{|l|}{ Area (ha) } \\
\hline Rice & 0.30 & 0.11 & 0.58 & 0.14 & 48.2 & 1.14 & 0.19 & 1.55 & 0.21 & 26.4 \\
\hline Maize & 1.14 & 0.27 & 1.24 & 0.27 & 8.0 & 1.05 & 0.17 & 1.53 & 0.22 & 31.3 \\
\hline Bean & 0.46 & 0.14 & 0.62 & 0.20 & 25.8 & 0.40 & 0.08 & 0.40 & 0.08 & 0 \\
\hline Cassava & 0.38 & 0.11 & 0.58 & 0.18 & 34.4 & 0.72 & 0.12 & 1.20 & 0.24 & 40.0 \\
\hline \multicolumn{11}{|c|}{ Production (kg) } \\
\hline Rice & 220.80 & 104.76 & 363.60 & 146.39 & 39.2 & 688.88 & 147.77 & 835.55 & 139.72 & 17.5 \\
\hline Maize & 1022.00 & 251.59 & 1185.33 & 288.39 & 13.7 & 742.61 & 117.79 & 1125.03 & 141.20 & 33.9 \\
\hline Bean & 50.66 & 19.84 & 61.33 & 21.33 & 17.4 & 9.56 & 2.50 & 9.56 & 2.50 & 0 \\
\hline Cassava & 157.06 & 79.78 & 299.06 & 170.55 & 41.7 & 607.90 & 172.92 & 970.86 & 225.37 & 37.3 \\
\hline
\end{tabular}

Source: Research results (2008).

Notes: $\mathrm{SE}=$ standard error of the mean.

Scenario $\mathrm{A}=$ current production after the land use change due to adoption of oil seeds activity.

Scenario $\mathrm{B}=$ potential production if the oil seeds activity was not adopted and therefore there was no land use change.

These outcomes clearly demonstrate land use change towards oil seed production. These figures are also corroborated by the final feedstock production, per family per year. When one compares the two scenarios, one can observe that the food produced by families, on average, decrease vis-à-vis the adoption of the oil seed activity. As the Table shows, roughly $42 \%$ less cassava and $39.2 \%$ less rice are produced by families in RC group due to the oil seed activity; and roughly $37 \%$ less cassava and $33.9 \%$ less maize are produced by families in JC group also due to the oil seed activity, which increases food insecurity of households in the region in question. Considering the farmers in the region in question as food net buyers, a decrease on family income could aggravate the lack of access to food, which also could lead to a food and nutrition insecurity situation or even aggravate the situation of those families that already are under a food insecurity condition 5 .

\section{Economic returns of oil seed production}

In addition to the analysis on the impacts of oil seed activity on local food production, it is also important to understand the economic impacts. Based on this, the gross margin is one of the main parameters for assessing resource use efficiency and it is calculated

\footnotetext{
5 According to the PNAD (Brazilian national household survey) carried out in $2004{ }^{[18]}$ roughly $50 \%$ of Brazilian rural families are under a certain level of food insecurity. Based on this, in another research carried out by our scientific group involving two rural communities in Tocantins State, around $84 \%$ of families were diagnosed with a mild level of food insecurity (data not shown). This figure calls the attention to the fact that programs, either governmental or not, that aim to fulfill social goals such as income generation and food access should take into account the food and nutrition security of families involved in this kind of initiative.
} 
by deducting the variable costs of each activity from the respective revenue, based on one year (in this case, the year of 2008). Moreover, gross margin can also be a proxy for the activity profitability in a specific farming system considering, for instance, unit of measurements, such as land size (per hectare) or value of livestock per head, for example ${ }^{[16,17]}$.

So, aiming at having an appropriate economic analysis, it is also important to state the differences between Jatropha curcas and Ricinus communis production, ex ante, before proceeding. Ricinus communis is an annual crop in which farmers cannot receive an official credit line (true at the time the study was conducted). In this way, the farmer must use a part of the credit, which was accessed for other purposes, towards oil seed production. Jatropha curcas, on the other hand, is a perennial crop in which farmers can obtain an official credit line offered by Banco da Amazonia (BASA). Furthermore, having this credit line gives the farmer the ability to repay the credit after four years of production rather than after the first year.

The gross margin for Ricinus includes the costs carried out by smallholders, such as, planting and harvesting. Whereas, the gross margin calculation for Jatropha does not take these costs into account. This is because the activities considered are done within the first year and at this time Jatropha smallholders do not have any financial burden. The gross margin estimation for Ricinus communis and Jatropha curcas can be seen in Table 4.

Table 4. Gross margin of oil seed activity production $(\mathrm{R} \$)$.

\begin{tabular}{lccccc}
\hline \multirow{2}{*}{ Item } & \multicolumn{2}{c}{$\begin{array}{c}\text { Ricinus communis } \\
\text { producers }\end{array}$} & \multicolumn{2}{c}{$\begin{array}{c}\text { Jatropha curcas } \\
\text { producers }\end{array}$} \\
\cline { 2 - 6 } & Mean & SE & Mean & SE & $p$-value \\
\hline Variable costs & 86.40 & 3.48 & - & - & - \\
Production value & 182.70 & 39.55 & 42.60 & 10.78 & 0.01 \\
Gross margin (GM) & 96.30 & 39.03 & 42.60 & 10.78 & 0.70 \\
GM per hectare & 42.99 & 15.94 & 14.84 & 3.02 & 0.97 \\
\hline
\end{tabular}

Source: Research results (2008).

Notes: SE = standard error of the mean.

Mann-Whitney test was applied to check the differences between the means $(p<0.05)$.

As Table 4 illustrates, the gross margin of Ricinus communs is considerably higher when compared to Jatropha curcas. One possible reason for this is the fact that Jatropha activity in the first year does not generate considerable yields to family farmers. It is important to highlight that even the productivity of Jatropha curcas during the first year is very low when compared to the minimum expected by the biodiesel company. Therefore, producing Jatropha might jeopardize the economic returns for farm families in the short and long term. The average production of Jatropha seeds in the first year is $42.5 \mathrm{~kg}$, per hectare, while the minimum expected by the biodiesel company is $100 \mathrm{~kg}$, per hectare (Figure 2). Therefore, current production is less than half of the minimum, which is a prominent reason many smallholders choose to cease production. When inquired about the following year of Jatropha cultivation, 5 families $(18.5 \%)$ responded that they would like to terminate production in order to cultivate conventional crops, such as, maize, rice and cassava. Roughly $41 \%$ of the families (11 smallholders) responded that they will observe production for one more year, i.e. to see if the productivity in the second year follows the first year's pattern, one should expect at least $50 \%$ fewer producers of Jatropha curcas in the sub-study region.

Another important fact is that the gross margin estimated for Jatropha curcas is lower than all other conventional crops, which are considered economically profitable, such as, maize, rice and 
cassava (Table 5). Jatropha is expected to become profitable after the fourth year, however, the low productivity in the first year, plus the lower gross margin, makes Jatropha curcas an unprofitable economic activity in the sense of farm income generation as advocated by the PNPB.

\section{- Ricinus producers $\square$ Jatropha producers}

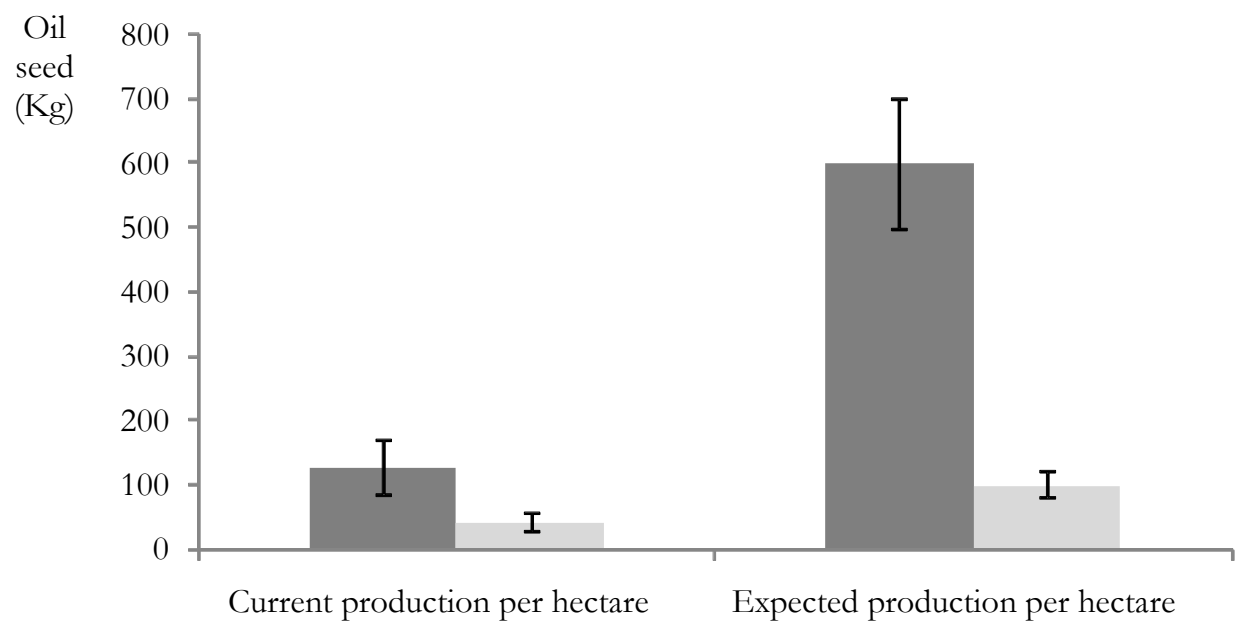

Figure 2. Jatropha and Ricinus production/hectare.

Source: Research results (2008).

Table 5. Gross margin of conventional crops and oil seeds $(\mathrm{R} \$)$.

\begin{tabular}{|c|c|c|c|c|c|}
\hline \multirow{2}{*}{ Gross margin } & \multicolumn{2}{|c|}{$\begin{array}{c}\text { Ricinus communis } \\
\text { producers }\end{array}$} & \multicolumn{2}{|c|}{$\begin{array}{c}\text { Jatropha curcas } \\
\text { producers }\end{array}$} & \multirow[b]{2}{*}{$p$-value } \\
\hline & Mean & SE & Mean & SE & \\
\hline Gross margin of cassava & $367.91^{\mathrm{ab}}$ & 217.28 & $965.45^{c}$ & 284.89 & 0.02 \\
\hline Gross margin of rice & $200.00^{\mathrm{ab}}$ & 146.99 & $237.14^{\mathrm{b}}$ & 71.73 & 0.55 \\
\hline Gross margin of maize & $546.84 b$ & 151.28 & $373.63 \mathrm{bc}$ & 52.49 & 0.03 \\
\hline Gross margin of oil seed & $96.30^{\mathrm{a}}$ & 39.03 & $42.60^{\mathrm{a}}$ & 10.78 & $<0.00$ \\
\hline
\end{tabular}

Source: research results (2008).

$\mathrm{SE}=$ standard error of the mean.

Mann-Whitney test was applied to check differences between means in rows and thus different letters show significant statistical difference $(p<0.05)$. Kruskal-Wallis test was applied to check differences among means in columns and thus different letters show significant statistical difference $(p<0.05)$.

The gross margin for Ricinus communis also presents a lower value when compared to other conventional crops in the sub-study region and, thus, low economic returns. This reflects the reality in Brazil, where smallholders put Ricinus communis aside and instead produce conventional crops. Not only the low productivity per hectare, but also the costs involved and the lack of technical assistance are making Ricinus 
an unprofitable activity for family farmers in the substudy region ${ }^{[19]}$.

The average production of Ricinus seeds was $127.71 \mathrm{~kg}$, per hectare, in the sub-study region while the minimum expected by the biodiesel company was 600 $\mathrm{kg}$, per hectare. The current production is much lower than the minimum expected by the company which might, like Jatropha curcas, be a strong reason for many smallholders to stop production. When inquired about the continuation of Ricinus production, for instance, 9 families $(36 \%)$ responded negatively, i.e. they will stop cultivating Ricinus communis in the following year, and $40 \%$ of the families (10 smallholders) responded that they will only continue with Ricinus if they have the opportunity to access official credit lines and technical assistance. As has been illustrated, the future of Ricinus communis production in the sub-study region is not optimistic and might jeopardize one of the targets of the PNPB, which establishes Ricinus as the main vegetable oil that should be used by family farmers for biodiesel production in Brazil.

In summary, the gross margin obtained from oil seed production is lower than the gross margin from conventional food crops production. Therefore, oil seed production, the alternative activity advocated by the PNPB, is not improving the local farm income. Moreover, as family farmers in the region are food net buyers, a decrease in their generated income could affect their access to food, as their purchase power will diminish. These results emphasize the fact that PNPB is not achieving one of its main goals, which is to decrease negative impacts on farm income generation and food and nutrition security of farm families.

\section{FINAL REMARKS}

Bioenergy and, especially, biodiesel is considered a renewable source of energy not only in Brazil, but also internationally. However, its production might be occurring without much needed caution, especially regarding its negative impacts on local food security. As presented in this paper, the oil seed production related to Jatropha curcas and Ricinus communis has led to land use changes since the land used previously to cultivate crops that is now being used to produce oil seed.

The oil seed activity in both sub-study regions diminishes the local food production. Moreover, the gross margin from oil seed activity is lower than the gross margin from conventional food crops production and, therefore, leads to a reduction in the farm family's income. These facts might reduce local access to food: (i) families have less food available for selfconsumption; (ii) as families are considered food net buyers, their access to food could also be compromised by reduced income. Based on this, oil seed production might have undesired effects on the food security of families. Moreover, roughly $56 \%$ of families in the RC group responded positively to food deficits during the year, and at the same time produced $25 \%$ less feedstock after integrating oil seed production. These outcomes address an important topic for policy and decision makers and highlight the fact that PNPB targets, regarding income generation and FNS, have not yet been met. Local food production and food security need to be supported and not harmed with the implementation of any new project.

This study is unprecedented in the region and the results are extremely important in helping to obtain an appropriate method for regional and national governments to subsidize clean energy production without harming the local food production. Therefore, helping Brazil to achieve regional sustainable development. Small-scale oil seed production in the Cerrado can now be better gauged in other parts of the Brazilian Legal Amazon Region because our study highlights one of the most discussed topics in bioenergy debate: oil seed production and its precedence over the local food security.

As the present study focuses only at family level in a specific region, we suggest that the study should be continued with larger sample and in the same or in other areas to get a more representative result. In addition, other studies should be carried out considering the biodiesel production at regional and national levels with the aim of attaining a broader idea of the biodiesel production in Brazil and the impacts on income and job generation, as well as food production.

\section{REFERENCES}

[1] Dubois O. How Good Enough Biofuel Governance Can Help Rural Livelihoods: Making sure that Biofuel Development Works for Small Farmers and Communities. Rome: Italy; 2008.

[2] Foof and Agriculture Organization of the United Nations. Bioenergy, food security and Sustainability - Towards an International Framework, 2008. 48 p. [cited 2009 Oct 10]. Available from: 
http://www.fao.org/fileadmin/user upload/foodclimate/H LCdocs/HLC08-inf-3-E.pdf

[3] Food and Agriculture Organization of the United Nations. Climate Change, Bioenergy and Food Security: Options for Decision Makers identified by Expert Meetings, 2008. 39 p. [cited 2009 Oct 26]. Available from: http://www.fao.org/fileadmin/user upload/foodclimate/H LCdocs/HLC08-inf-5-E.pdf

[4] Food and Agriculture Organization of the United Nations. Climate Change, Bioenergy and Food Security: Civil Society and Private Sector Perspectives, 2008. 97 p. [cited 2009 Oct 26]. Available from: http://www.fao.org/fileadmin/user upload/foodclimate/H LCdocs/HLC08-inf-6-E.pdf

[5] Food and Agriculture Organization of the United Nations. Bioenergy Policy, Markets and Trade and Food Security, 2008. 42 p. [cited 2009 Oct 26]. Available from: http://ftp.fao.org/docrep/fao/meeting/013/ai788e.pdf

[6] UN-Energy. Sustainable Bioenergy: A Framework for Decision Makers, 2007. 64 p. [cited 2009 Oct 26]. Available from:

http://www.fao.org/docrep/010/a1094e/a1094e00.htm

[7] Food and Agriculture Organization of the United Nations. The State of Food and Agriculture. Biofuels: prospects, risks and opportunities, 2008. 116 p. [cited 2009 Oct 26]. Available from: http://www.fao.org/docrep/011/i0100e/i0100e00.htm

[8] Pingali P, Raney T, Wiebe K. Biofuels and Food Security: Missing the Point. Review of Agricultural Economics. 2008;30(3):506-16.

[9] Cotula L, Dyer N, Vermeulen S. Fuelling exclusion? The biofuels boom and poor people's access to land. FAO and IIED. 2008. 82 p. [cited 2009 Oct 26]. Available from: http://www.iied.org/pubs/pdfs/12551IIED.pdf

[10] Nass LL, Pereira PAA, Ellis D. Biofuels in Brazil: An Overview. Crop Science. 2007;47(6):2228-37.

[11] Programa Nacional de Produção e Uso de Biodiesel. 2005 [acesso em 26 out 2009]. Disponível em: http://www.biodiesel.gov.br/programa.html
[12] II Conferência Nacional de Seguranca Alimentar e Nutricional. A construção de uma Política Nacional de Segurança Alimentar e Nutricional. Olinda (PE), Brazil, 2004 [acesso em 22 mar 2011]. Disponível em: http://www.mds.gov.br/saladeimprensa/eventos/seguranca -alimentar-e-nutricional/ii-conferencia-nacional-deseguranca-alimentar-e-nutricional-1

[13] III Conferência Nacional de Seguranca Alimentar e Nutricional. Por um Desenvolvimento com Segurança Alimentar e Nutricional, Soberania e Sustentabilidade. Fortaleza (CE), Brazil, 2007 [acesso em 22 mar 2011]. Disponível em: http://www.mds.gov.br/saladeimprensa/eventos/seguranca -alimentar-e-nutricional/iii-conferencia-nacional-deseguranca-alimentar-e-nutricional

[14] Instituto Brasileiro de Meio Ambiente Ecossistemas Brasileiros, 2007 [acesso em 5 jan 2008]. Disponível em: http://www.ibama.gov.br

[15] Ministério do Desenvolvimento Agrário. Biodiesel no Brasil: resultados sócio-econômicos e expectativa futura, 2007 [acesso em 11 dez 2009]. Disponível em: http://pt.scribd.com/doc/23130605/Biodiesel-no-Brasil

[16] Doppler W. Farming and Rural Systems - State of the Art in Research and Development. In: Doppler W, Calastrava J (Eds.) Technical and Social Systems Approaches for Sustainable Rural Development. Margraf Verlag: Weikersheim; 2000a.

[17] Doppler W. Setting the Frame: The Environmental Perspectives in Rural and Farming Systems Analyses. In: Doppler W, Koutsouris A (Eds.) Rural and Farming Systems Analysis. Environmental Perspectives. Markgraf Verlag: Weikersheim; 2000b.

[18] Instituto Brasileiro de Geografia e Estatística. Diretoria de Pesquisas. Departamento de População e Orçamentos Familiares 2002-2003: análise domiciliar e estado nutricional no Brasil, 2004 [acesso em 11 dez 2009]. Disponível em: http://www.ibge.gov.br/home

[19] Garcez CAG, Vianna JNS. Brazilian Biodiesel Policy: Social and environmental considerations on sustainability. Energy. 2009;34(5):645-54. 